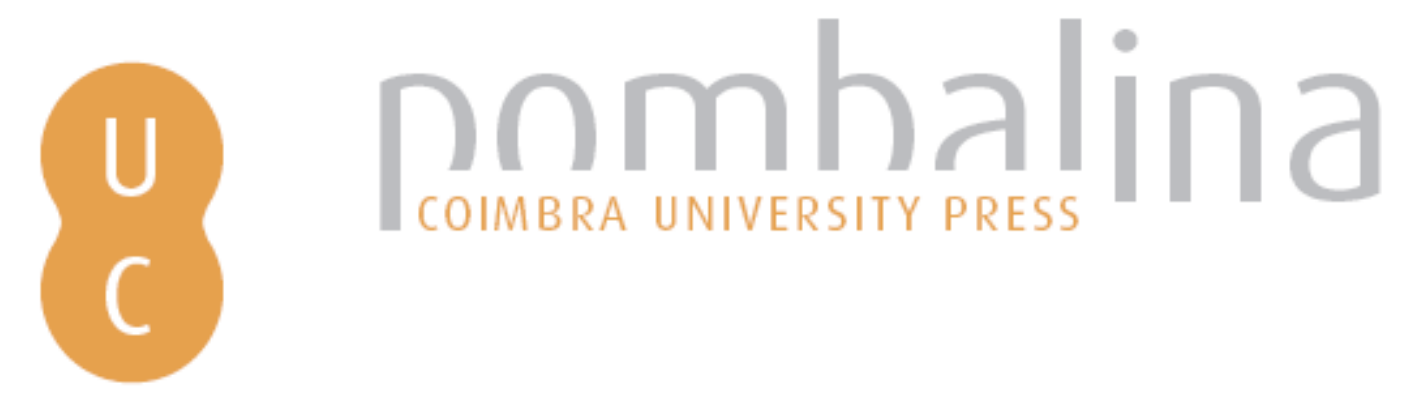

\title{
"A fatal máquina": Margarida de Sabóia (1589-1656), Duquesa de Mântua e vice- rainha de Portugal
}
Autor(es):
Raviola, Blythe Alice
Publicado por: Imprensa da Universidade de Coimbra
URL
persistente:
URI:http://hdl.handle.net/10316.2/32345
DOI:
DOI:http://dx.doi.org/10.14195/978-989-26-0604-0_4
Accessed : $\quad$ 26-Apr-2023 12:53:02

A navegação consulta e descarregamento dos títulos inseridos nas Bibliotecas Digitais UC Digitalis, UC Pombalina e UC Impactum, pressupõem a aceitação plena e sem reservas dos Termos e Condições de Uso destas Bibliotecas Digitais, disponíveis em https://digitalis.uc.pt/pt-pt/termos.

Conforme exposto nos referidos Termos e Condições de Uso, o descarregamento de títulos de acesso restrito requer uma licença válida de autorização devendo o utilizador aceder ao(s) documento(s) a partir de um endereço de IP da instituição detentora da supramencionada licença.

Ao utilizador é apenas permitido o descarregamento para uso pessoal, pelo que o emprego do(s) título(s) descarregado(s) para outro fim, designadamente comercial, carece de autorização do respetivo autor ou editor da obra.

Na medida em que todas as obras da UC Digitalis se encontram protegidas pelo Código do Direito de Autor e Direitos Conexos e demais legislação aplicável, toda a cópia, parcial ou total, deste documento, nos casos em que é legalmente admitida, deverá conter ou fazer-se acompanhar por este aviso. 


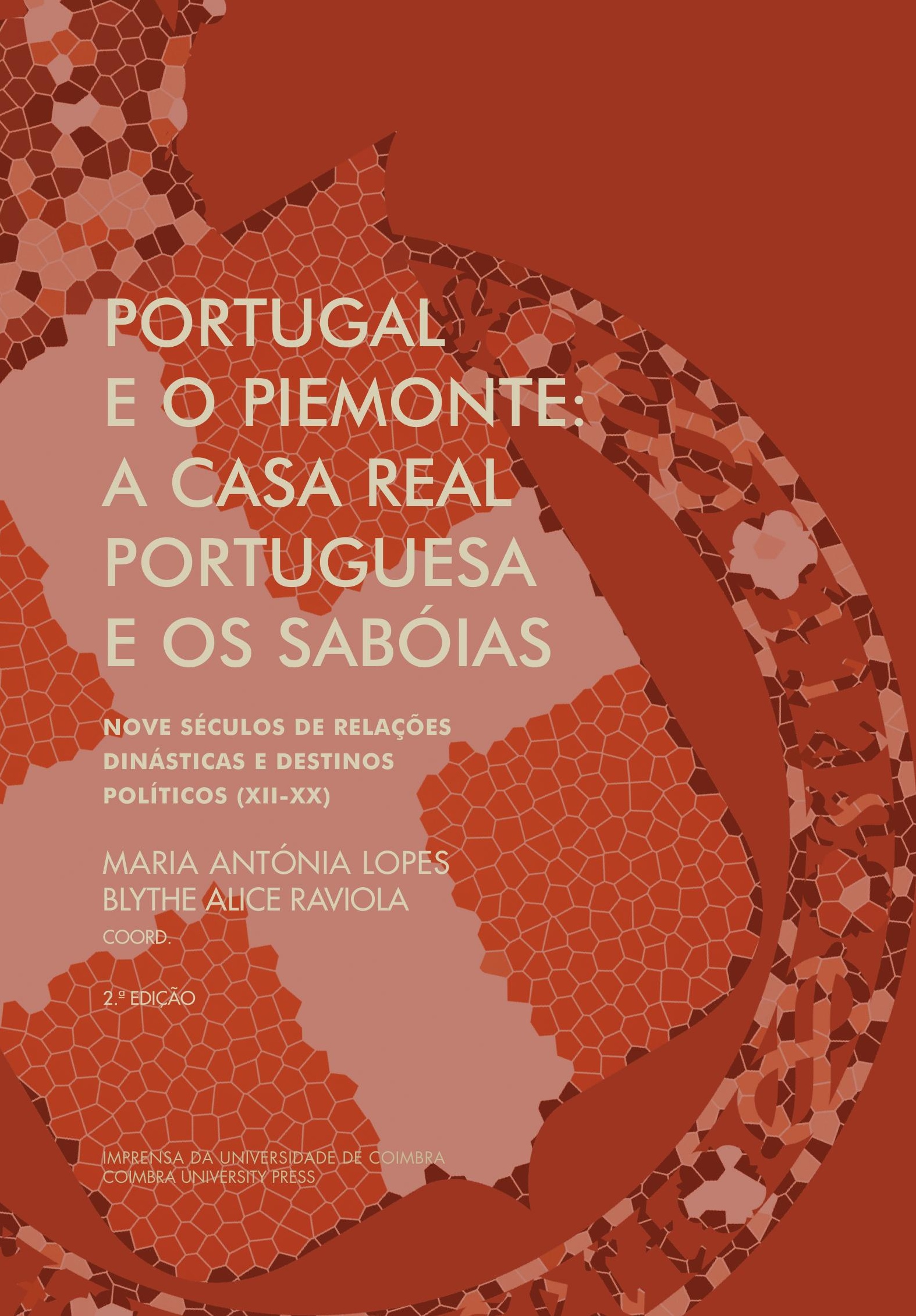




\section{Blythe Alice Raviola}

Compagnia di San Paolo di Torino/Università di Torino

“A FATAL MÁQUina”.

\section{MARGARIDA DE SABÓIA (1589-1656), DUQUESA DE MÂNTUA E VICE-RAINHA DE PORTUGal}

\section{Um vazio historiográfico}

A lenda negra da dominação espanhola em Itália e no mundo tem muitas faces e uma delas, pouco conhecida e de resto menor, sobrepõe-se ao rosto de Margarida de Sabóia, quarta filha do duque Carlos Manuel I e de Catarina Micaela de Habsburgo. A sua aventura dinástica e humana, que em parte já abordei em relação a alguns aspectos específicos ${ }^{1}$, levou-a a ser vice-rainha de Portugal em anos dramáticos, de 1635 a 1640, sem que se saiba muito do seu governo, e com uma generalizada e pesada condenação por parte da historiografia (exígua) que dela se ocupou.

Estas páginas não pretendem revalorizá-la, nem podem ambicionar reconstruir com exaustão aquele período crucial, visto que as próprias fontes salvo uma pesquisa ulterior necessária através das fontes espanholas e portuguesas - parecem fugir ao assunto em causa, para insistir sobre outros

\footnotetext{
* Quero agradecer ao pessoal dos Arquivos Nacionais da Torre do Tombo (Lisboa) e da Biblioteca Nacional de Portugal (Lisboa) por me terem facilitado a pesquisa no pouco tempo de que de que dispus, ao mesmo tempo que dirijo o meu habitual reconhecimento aos funcionários e documentalistas do Arquivo de Estado de Turim. Almudena Pérez de Tudela, amiga e correspondente de há anos, ajudou-me na investigação e na reprodução de fontes importantes. Este ensaio, fruto de pesquisas realizadas, enriqueceu-se com sugestões graças aos conselhos e ao diálogo estabelecido com Maria Antónia Lopes e Isabel Drumond Braga, para quem vai o meu sincero testemunho de estima.

${ }^{1}$ Sobre o problema da regência de Margarida permito-me remeter para RAVIOLA, B. A., 2008; sobre as questões ligadas à cobrança do seu dote: RAVIOLA, B. A., em vias de publicação ${ }^{1}$; por fim, para um breve perfil no contexto internacional: RAVIOLA, B. A., em vias de publicação ${ }^{2}$.
} 
aspectos e problemas da vida de Margarida. O objectivo é o de tornar mais claro o destino político desta mulher, para além de tratar das relações entre o Piemonte, Espanha e Portugal, antigas e persistentes, mas jamais considerados pela literatura científica italiana. O texto desenrola-se, assim, entre a fase inicial da biografia da infanta e o culminar da sua carreira, detendo-me aqui em particular sobre as relações com Madrid e proporcionando algumas hipóteses de leitura sobre a sua prolongada e nebulosa estada em Lisboa.

Uma espécie de damnatio memorice parece, de facto, ter atingido Margarida, forçosamente em comum com o execrado domínio dos reis de Espanha, Filipe II, III e IV, segundo a numeração espanhola, correspondentes a Filipe I, II e III de Portugal para a história lusitana. O seu nome aparece apenas duas vezes no motor de busca dos Arquivos Nacionais da Torre do Tombo e nenhuma nos sumários da Chancelaria da época de Filipe III (IV), se bem que tenha sido ela, nos anos aqui considerados, a representar a Coroa em Lisboa. As razões do esquecimento são facilmente compreensíveis, mas estimulam ainda mais a investigação sobre a última fase da forçada união ibérica, na complexidade do cenário político europeu, percorrido então pelos estremecimentos das revoltas intestinas (Catalunha e Messina) e transformações epocais (a Fronda, a premente revolução inglesa).

A historiografia portuguesa tradicional, de que podemos aqui apenas apresentar um breve resumo, ou a liquida em poucas palavras ou apaga-a de todo. É exemplificativo, neste sentido, o silêncio das principais enciclopédias em língua portuguesa, que não concedem ao seu perfil nem sequer uma linha em seu desabono. O Diccionario bibliographico portuguez, de Inocêncio Francisco da Silva, de 1862, não a nomeia e o mesmo se pode dizer de outros repertórios, nos quais a sequência das Margaridas é sempre a mesma: Margarida de Áustria, duquesa de Sabóia (1480-1530), isto é, a filha de Maximiliano I, esposa de D. João de Aragão e Trastâmara, e, em segundas núpcias, de Felisberto II, duque de Sabóia; as rainhas da Dinamarca e Noruega; algumas santas (M. da Escócia e M. da Hungria); Margarida de Habsburgo, duquesa de Parma, a célebre governante dos Países Baixos (1522-1586); Margarida de Valois; Margarida de Angoulême 
e a rainha de Itália, Margarida de Sabóia (1851-1926)². Esta última merece uma breve nota também na Grande Enciclopédia portuguesa e brasileira 3 e no Diccionario enciclopedico U.T.E.H.A impresso no México em $1953^{4}$, em que são retomadas quase à letra as informações sobre a rainha, que se alinha também com a beata Margarida de Sabóia (1382-1464), viúva de Teodoro II Paleólogo, marquês de Monferrato ("a sua festa é a 7 de Novembro»). A aproximação é curiosa se se pensar que a beatificação da marquesa foi favorecida pela sua homónima do século $\mathrm{XVII}^{5}$, partilhando em comum não só o facto de pertencerem à Casa da Sabóia, mas também pelo casamento de forte valência dinástica com o soberano de Monferrato, ambicionado pela sua família tanto no século XV, como nos dois séculos sucessivos.

$\mathrm{Na}$ verdade, os repertórios italianos também não são mais generosos. A Enciclopédia Treccani dedica a Margarida de Sabóia-Gonzaga um verbete anónimo e assaz breve, no qual são recordados de passagem os pais, as núpcias, o exílio forçado de Mântua e a governação de Portugal "com funções puramente representativas» ${ }^{6}$. Em contrapartida, no óptimo Dizionario Biografico degli Italiani o seu perfil é bastante pormenorizado até 1634, tornando-se vago depois, na ausência de estudos mais ricos, sobre o período hispano-português e sobre o epílogo régio da existência da duquesa de Mântua?

Escapam, assim, a complexidade da vida da infanta e os traços salientes do seu carácter, em nada inclinado a deixar-se dobrar de maneira passiva pelos acontecimentos.

2 Diccionario bibliographico portuguez, 1862, retomado quase à letra na actualização da Enciclopédia Luso-brasileira de Cultura Verbo, vol. 18, pp. 1303-1308.

3 Grande Enciclopédia portuguesa e brasileira, s.d., vol. 16, p. 290.

${ }^{4}$ Diccionario enciclopedico U.T.E.H.A., 1953, vol. VII, p. 212. De resto, em quase todos os repertórios citados, ao rei Filipe III (IV de Espanha) são reservadas frases concisas e quase não se dá notícia do período português.

5 Para um perfil de Margarida de Sabóia Paleólogo cf. PARUSSO, G., 2007. Sobre a sua beatificação: QUAZZA, R., 1930, p. 114; MOSTACCIO, S., 1999, pp. 465-469; RAVIOLA, B. A., 2008, p. 334; GIACHINO, L., 2011, pp. 73-104.

${ }^{6}$ Passível de consultar online no endereço: http://www.treccani.it/enciclopedia/margherita-di-savoia-duchessa-di-mantova

7 TAMALIO, R., online: http://www.treccani.it/enciclopedia/margherita-di-savoia-duchessa-di-mantova-e-di-monferrato_(Dizionario-Biografico)/ 


\section{A formação, a herança materna e a condição ducal}

A historiografia piemontesa sublinha já há algum tempo o forte peso da educação espanhola dada por Catarina Micaela e pelas suas governantas, D. Sancha de Gusmão e Mariana de Tassis, aos filhos que teve de Carlos Manuel I ${ }^{8}$. E se esse traço foi profundo nos rapazes, que fizeram o seu percurso de aprendizagem na corte do tio Filipe III com a orgulhosa esperança de poderem ser admitidos na linha da sucessão9 ${ }^{9}$, não foi menos marcante nas raparigas, cada uma à sua maneira, que tiveram sempre presente a origem real da mãe. Duas delas cedo foram introduzidas no mercado matrimonial peninsular e europeu e, assim, Margarida e Isabel (1591-1626) uniram-se em casamento no mesmo dia - numa cerimónia que ficou proverbial ${ }^{10}$ - respectivamente com o futuro duque de Mântua Francisco IV e com o duque de Módena Afonso d'Este. Para as irmãs menores, Maria Apolónia (1594-1656) e Francisca Catarina (1595-1640), os projectos de casamento com outros príncipes esfumaram-se no nada, mas ambas, desde a mais tenra idade, tinham alimentado uma fé sincera e tenaz, em tudo em sintonia com a da mãe e de manifesto cunho mariano, que as levou a vestir sem sacrifício o hábito de terceiras franciscanas. A condição monacal, de resto, não as impediu, muito especialmente Maria Apolónia, de amadurecer notáveis conhecimentos políticos que fez frutificar como conselheira, primeiro do pai, depois dos irmãos Vítor Amadeu, Tomás e Maurício ${ }^{11}$.

Já desde criança, a mais voluntariosa das quatro parece ter sido Margarida, a quem o seu biógrafo - Romolo Quazza - atribui um carácter decidido e obstinado ${ }^{12}$. Como referiu ao duque Carlos Manuel o seu mordomo Langosco della Motta pouco depois da morte da amada infanta Catarina,

8 MERLIN, P., 1991, pp. 4-11, 17-18; MERLIN, P., 2008. Sobre a importância do papel materno na educação dos príncipes e princesas é útil, também para confronto, o amplo estudo de PAOLI, M. P., 2008, sobre o grão-ducado da Toscana.

9 DEL RÍO BARREDO, M. J., 2006.

10 VARAllo, F., 1999; BesutTi, P., 1999.

11 RAVIOLA, B. A., em vias de publicação.

12 QUAZZA, R., 1930, p. 11. 
"As sereníssimas princesas gozam de perfeita saúde e é uma satisfação observá-las, em especial a princesa Margarida, que tem um espírito que tudo transcende, "dize que el principe de España su tio, aunque se case agora con otra, que ha presto de embiudar y casar segunda vez forzosamente con ella”. Deus o permita, que esta seria a maior alegria que podia haver em Espanha!"13

A brincalhona boutade infantil - expressa, repare-se, em língua materna - esconde um fundo de verdade, ou melhor denuncia aquela ilimitada admiração pelos Habsburgos de Espanha, que jamais abandonaria Margarida. Aquele "espírito que tudo transcende", isto é aquele carácter superior, como diríamos nós hoje, foi outra constante da personagem, dotada de uma força de espírito fora do comum e sempre plenamente consciente da sua posição. Evidente nalgumas fontes e amplificada pelos comentadores sucessivos, a atitude segura da princesa contribuiu provavelmente para fixar, já durante a sua existência, a imagem negativa que de longe lhe sobreviveu. Não é por acaso que o outro seu retrato biográfico mais célebre tenha sido elaborado por uma escritora no auge da fama, mundana e literária, como foi Maria Bellonci, e tudo foi lançado no registo de ambição, da obstinação e da sede do poder.

As núpcias italianas, bem longe dos seus sonhos de menina, foram felizes mas sobretudo estratégicas, destinadas a reabrir o diálogo entre os duques de Sabóia e Mântua na disputa do domínio de Monferrato. A jovem infanta chegou à corte dos Gonzagas cheia de expectativas em relação ao seu futuro e enrijecida pela etiqueta espanhola, pelo menos nas memórias de Bellonci, decalcadas das dos embaixadores venezianos. Quando fez a sua entrada na cidade, exibia "uma carinha com tais ares de majestade tão presunçosa que convencia o povo" ${ }^{4}$. Uma vez no palácio ducal, sempre obediente às ordens da governante Mariana de Tassis, que a tinha acom-

13 ASTo, Corte, MPRE, Lettere ministri, Spagna, m. 9, 15 de Janeiro de 1598. A citação que está no texto traduz-se do seguinte modo: "Diz que o príncipe de Espanha, seu tio, ainda que case agora com outra, que cedo há-de enviuvar e casar segunda vez, forçosamente com ela". Agradeço a Almudena Pérez de Tudela por me ter assinalado este sugestivo testemunho.

14 BELLONCI, M., 1963, p. 232. 
panhado a Mântua, estava "com grande sossego, parecia imóvel e não dava inteira satisfação de si» ${ }^{15}$. A opinião da escritora é, portanto, inapelável: "Margarida de Sabóia perdera a sua soberba, a sua força e a ilimitada estima de si e do próprio sangue» 16 .

Poder-se-á perguntar se, para além das cortantes observações de Quazza e Bellonci, a aspiração de Margarida ao poder não retomava, na realidade, uma visão toda ela ainda quinhentista do poder no feminino. Se no século XVI, como mostrou F. Cosandey, era ainda praticado e bastante tolerado ${ }^{17}$, a partir do século seguinte as regências começaram a ser vistas a uma luz sinistra, enquanto momentos de profunda fraqueza do trono e, ao mesmo tempo, de perigoso estímulo ao facciosismo cortesão ${ }^{18}$. Não é preciso invocar os exemplos ilustres de Catarina de Médicis ou da unicidade do reino de Isabel I Tudor. No contexto saboiano, basta dirigir a atenção para o governo das duas Madames Reais, por antonomásia, isto é, Cristina de Bourbon e a sua nora Maria Joana Baptista de Sabóia-Nemours, para evocar os duros juízos dos detractores seus contemporâneos e da historiografia sucessiva ${ }^{19}$.

Em geral, as mães ensinavam às filhas de sangue principesco a comportarem-se segundo os cânones de obediência, de virtude e de cego sustentáculo da linhagem do marido. Assim tinha sido para numerosas esposas da Casa Médicis, saídas de (ou chegadas a) Florença ${ }^{20}$, e assim acontecia na maior parte das cortes europeias. Margarida, porém, tinha crescido órfã de mãe e tinha respirado a ambição e também a atitude de comando do pai, Carlos Manuel, que, durante alguns dias, quando ela tinha apenas catorze anos, lhe conferiu o poder ad interim do ducado ${ }^{21}$. Este é um episódio que Quazza lê como decisivo na psicologia de Margarida, talvez acentuando-lhe o seu real alcance, mas que decerto prendeu a precoce consciência da infanta nos meandros das questões políticas.

15 Assim refere um observador veneziano, in MERLIN, P., 1991, p. 24.

16 BELLONCI, M., 1963, p. 231.

17 COSANDEY, F., 2000; Idem, 2008.

18 CRAVERI, B., 2005, pp. 11-24.

19 Sobre a rainha Cristina veja-se ROSSO, C., 2008; sobre Maria Joana Baptista é essencial ORESKO, R., 2004. Cf. também NALDI, C., GIANASSO, E., ROGGERO, C. (ed.), 2011.

20 PAOLI, M. P., 2008, em particular pp. 101 e segts.

21 QUAZZA, R., 1930, p. 11. 
A frustração por não poder reger nem o Monferrato nem o Mantuano, por morte do marido; a deterioração das relações entre a sua família de origem e a adquirida, durante a guerra de sucessão do ducado (1627-1631); a angústia de ter de abandonar ao seu destino a única filha, Maria, deveriam ter alimentado em Margarida a raiva e a vontade de desforra que a correspondência diplomática lhe atribui. Assim, depois de uma prolongada estada em Turim, sobre a qual as notícias são esporádicas, mas interessantes $^{22}$, e o regresso a Mântua por alguns anos, a duquesa não perdeu a ocasião de se mostrar ostensivamente entre os embaixadores espanhóis e despertar hostilidades e suspeitas aos franceses, apoiando quase abertamente as razões dos primeiros durante as negociações da paz de Cherasco ${ }^{23}$.

De Madrid, Paris e Turim, as suas manobras eram observadas com apreensão. Em Outubro de 1633 teve uma forte discórdia com Luís XIII, que a considerava responsável pelas pretensões de Maria, que entretanto tinha casado com o duque Carlos de Rethel, neto de Carlos I Gonzaga-Névers, em matéria de governo de Mântua. O rei de França ordenou-lhe que abandonasse a capital dos Gonzagas e tal provisão provocou muito alvoroço, assim como a sua partida da cidade lombarda. Margarida, obrigada a partir, levantou problemas de hospitalidade aos estados vizinhos, que não se queriam comprometer demasiado, nem com a França nem com a Espanha. Segundo um observador saboiano, o arcebispo de Otranto, monsenhor Gaetano Coxa, que tinha sido correspondente de Madrid, Francisco I d'Este tinha-a convidado para se deslocar a Sassuolo para superar as dificuldades diplomáticas: «tendo o senhor duque de Módena o seu estado no meio do de Mântua, de Veneza, do Papa e de Milão, desejava levantar as gelosias aos vizinhos, mas fosse como fosse, a senhora infanta não mostrou gosto de ir a Sassuolo e passou de imediato a Cremona» ${ }^{24}$. Ali, numa cidade neu-

\footnotetext{
22 Em 1627, por exemplo, no encalço da deflagração da segunda guerra de sucessão de Mântua e do Monferrato, foi-lhe dedicado o panegírico intitulado La Margherita, recitado na sua presença na catedral de Turim, a 20 de Julho, dia onomástico da santa antioquiana. Segundo o parecer partilhado por Luisella Giachino, o requintado elogio pretendia vincar a adesão espanhola da infanta e, simultaneamente, «encorajar uma eventual reviravolta devota da princesa" (GIACHINO, L., 2011, p.80).

23 AGS, Estados pequeños de Italia, legajo 3830, cc. 52 e 53.

${ }^{24}$ ASTo, Corte, MPRE, , Lettere ministri, Spagna, m. 25, fasc. 2, Minute di lettere del Coxa, 1631-34, c. 25/2, 18 de Outubro de 1633.
} 
tral do estado de Milão, encontrou o padre Bergera, que os irmãos Vítor Amadeu I e Maurício lhe tinham mandado ao encontro. Este último, o cardeal, fez-lhe destinar uma pensão de 1500 ducados por mês "para que a senhora infanta tenha maior comodidade para se manter com o decoro das suas qualidades» ${ }^{25}$ e entre 1633 e 1634, o duque de Sabóia ficou muito atento às manobras da irmã, que entretanto se tinha transferido para Pavia e gozava dos serviços do barnabita Mansueto Merati: os interesses da princesa, defendia não sem razão Vítor Amadeu, "também são os meus" e não andavam descurados 26 .

\section{3. "A fatal máquina". A nomeação para o governo de Portugal}

Como já tive ocasião de mostrar ${ }^{27}$, a nomeação para vice-rainha de Portugal não foi casual, nem ditada por especulações internas da corte de Madrid, que também tinha necessidade de um peão mais ou menos neutro para colocar num ponto crítico do seu xadrez europeu. Foi a própria Margarida a conduzir o primo em direcção à sua promoção e a propor-se como válido sustentáculo da coroa. Com uma carta imperiosa ao conde-duque de Olivares, na qual insistia ser "filha de tal mãe», para além de viúva, e portanto digna de um tratamento de consideração, a duquesa suscitou um certo clamor, e a arenga, de Março de $1634^{28}$, deve ter atingido o alvo, visto que poucos meses depois lhe foi anunciado o novo e prestigioso encargo.

Os preparativos da transferência de Margarida, de Espanha para Portugal, foram cuidadosos e podemos contar com um interessante catálogo do pessoal, dos géneros alimentícios e dos utensílios de uso quotidiano destinados a seguir a infanta até Lisboa ${ }^{29}$. A princesa italiana teria tido à sua

25 Idem.

26 Ibidem, c. 31/1, carta de Vítor Amadeu a monsenhor Coxa, 22 de Julho de 1634.

27 RAVIOLA, B. A., 2008, p. 338; RAVIOLA, B. A., em vias de impressão.

28 AGS, Estados pequeños de Italia, legajo 3835, c. 189, Margarida ao "conde mi Señor», de Pavia, 12 de Março de 1634.

29 AGP, Histórica, caja 117, Recepciones y hospedajes de soberanos y principes extrangeros, Princesa Margarita de Saboya en 1634. Quero agradecer à colega Silvia Mitchell, da Universidade de Miami, por me ter indicado a fonte. 
disposição trinta e oito servidores, entre os quais o confessor, um tesoureiro, um guarda-roupa, alguns cozinheiros e camareiros, o leiteiro, o cabeleireiro (Lorenzo Gastaldo, "barbeiro"), o reposteiro Bartolomeo Fonzio e o "mestre de estado" Bartolomé Masete ${ }^{30}$. Todos assalariados com rações de carne e vinho - parte do qual trazido expressamente de Turim -tinham, com outros, a função de organizar e dispor dos bens e bagagens da "casa de la Reyna nostra señora" 31 , segundo as modalidades aplicadas em Espanha às mulheres de condição real ${ }^{32}$. Entre os objectos levados em viagem, contam-se: algumas peças de tapeçaria, uma escrivaninha de ébano, um pouco de prataria, vários instrumentos de cozinha (facas, uma balança de madeira, uma centena de pratos e bandejas de madeira), numerosas provisões de alimentos, entre as quais, porções de carne, fruta, enchidos, pão e um provimento de velas. As contas de gestão das despesas correntes da corte de Margarida, de resto fragmentárias e extensivas a 1644, ficam para um estudo mais cuidadoso, mas são significativas as palavras «bureo de la Reyna", que se encontram ao fundo de muitas páginas do registo e que remetem, de facto, para um secretariado, um bureau, incumbido de cuidar da sua pessoa e do seu núcleo mais restrito. A assinatura dos documentos a seu favor era do próprio punho de Filipe IV e no princípio do desempenho do cargo a cifra estabelecida para manter a infanta rondava os 15.000 reais 33 .

Faziam também parte do seu séquito alguns nobres saboianos e outros provenientes de diferentes partes de Itália, como o marquês Ludovico Forni, de origem modenesa ${ }^{34}$, que acompanhou «a Espanha a senhora infanta D. Margarida de Sabóia, duquesa de Mântua, e encarregada por Vossa Majestade do governo de Portugal». Ao dirigir-se ao rei, Forni explicava que o seu cargo era também o de resolver alguns negócios ducais, com explícita referência aos dotes de Margarida ainda por receber:

\footnotetext{
30 O elenco em loc. cit, fls. 51-52.

31 Idem, f. 6.

32 LABRADOR, F., 2009.

33 AGP, Histórica, caja 117, cit., fls. 72-74.

34 MANNO, A., ad vocem, agora acessível online no endereço http: //www.vivant.it.
} 
"e porque antes da partida dessa senhora do Piemonte, havia algumas divergências no ajuste dos seus dotes, e enquanto esperava o duque de Sabóia que vinha à eleição dos avaliadores e resolver estes interesses para acabar com qualquer motivo imaginável de lamento, face à imprevista notícia da sua viagem a Espanha, sobre o que enviou de imediato correio... a Génova com ordem de vir tratar das contas finais do seu crédito... e de resolver em quatro anos os seus interesses.»35

A questão, na realidade, revelar-se-ia bem mais complicada do que o previsto, uma vez que dizia respeito também à cobrança do dote de sua mãe, Catarina Micaela ${ }^{36}$, e teria ocupado boa parte dos pensamentos de Margarida e dos seus agentes ao longo dos anos quarenta e cinquenta do século XVII. Todavia, a Vítor Amadeu I, a presença da irmã na corte espanhola e com um cargo de tal importância, parecia abrir uma espiral importante nas relações diplomático-económicas entre o ducado e a Coroa, sem contar que a ausência de Margarida, de Itália, tornava mais distendido o clima com Mântua.

O próprio Forni oferecia do soberano e da sua entourage um retrato impiedoso, que trazia à luz o poderio exclusivo de Olivares: " têm o rei efeminado e fazem com que se alimente, na maior parte do tempo, com música, a composição de música e poesia e com mulheres; e unem-se para fazer com que não penetre no âmago dos negócios, logrando-o com conselhos segundo os seus interesses e para onde se inclina o conde-duque, ninguém ousa contradizê-lo, especialmente por todos serem seus sequazes»37. Neste ambiente, Filipe IV, quase uma marioneta dos seus próprios homens de confiança, não se dava conta da contínua dilapidação de dinheiro, nem do descontentamento que as manobras do seu ministro favorito suscitavam no reino e nos seus domínios:

"O rei é o príncipe mais roubado e maltratado do mundo, estando unidos para esbulhar os seus rendimentos, o ouro e a prata das Índias e todos

35 ASTo, Corte, MPRE, Lettere ministri, Spagna, m. 25, fasc. 5, c. $1 / 6$, memorial do marquês Forni de 18 de Abril de 1635.

36 MONGIANO, E., em vias de impressão.

37 ASTo, Corte, MPRE, Lettere ministri, Spagna, m. 25, fasc. 5, c. 2/4, s.d. 
enriquecem, particularmente os parentes e partidários do conde-duque... Os Portugueses estão muito pouco satisfeitos e fartos dos espanhóis por terem sido tirados do dito reino, desde que o têm, 56 milhões"38.

Assim, do ponto de vista lusitano, a chegada de Margarida de Sabóia quase sempre designada, nas fontes oficiais e locais, como "a duquesa de Mântua» - fez coincidir e selar "a fatal máquina» urdida pelo conde-duque de Olivares contra o povo português. A feliz expressão provém de um tratado intitulado Évora gloriosa, publicado pelo jesuíta Francisco da Fonseca, em 1728, no prosseguimento de Évora ilustrada, do confrade Manuel de Fialho ${ }^{39}$. A dedicatória a um cardeal espanhol, monsenhor Álvaro de Cienfuegos, e o tom afável da premissa que retira de um antigo adágio "Villa por villa, Valladolid en Castilla; ciudad por ciudad, Évora en Portugal»40 - parece deixar para trás das costas a acérrima rivalidade entre as duas nações ibéricas. Todavia, Évora, motor das revoltas anti-espanholas, encontra-se no centro da cena e a sua história, "profana" e "pia» segundo a subdivisão do autor, não pode omitir o momento de máxima laceração com os Habsburgos antes do advento dos Braganças e do futuro luminoso de devoção e alto número de fundações eclesiásticas.

Segundo as suas palavras e as de Fialho, a relação dos Portugueses com a monarquia espanhola ficou comprometida quando Filipe III (IV), ou melhor, o conde-duque de Olivares, impuseram um enésimo novo tributo ao país para sustentar as campanhas da Flandres e contra a Catalunha. Olivares, «Ou por ódio que tinha aos portugueses, ou porque queria suprir com o nosso ouro os imensos gastos daquelas guerras» ${ }^{41}$, não se ficou por aí e a partir do momento em que os governadores provinciais, «magoados da

\footnotetext{
38 Idem.

39 FONSECA, F., 1728. É curiosa e notável a "Advertência do impressor" romano: "A língua portuguesa é tão pouco usada nestes nossos países que esta é a primeira vez que a falaram os meus caracteres, sendo necessário para tal fim não só formar novas letras, mas, para além disso, copiar o original ao modo daqueles que copiam as pinturas, maravilhando-se os compositores não pouco por verem que falavam com a estampa aquilo que não sabiam com a língua, e por isso deverá o benévolo leitor perdoar benignamente os erros que encontra na impressão do texto e apostilhas marginais».

${ }^{40}$ Idem, p. 3. Segundo Fonseca, o mote era repetido com frequência pelo imperador José I.

41 Ibidem, p. 157.
} 
ruína da pátria», não tiveram coragem de aplicar o decreto, "mandou em 1634 por governadora de Portugal dona Margarita duquesa de Mântua, e por seu colateral o marquês de la Puebla para que fossem executores desta sua [como tínhamos antecipado] fatal máquina» ${ }^{42}$. Segundo uma análise recente, a escolha tinha sido inadequada às contingências, não obstante a candidata ter até ascendência portuguesa, por uma vez oportunamente recordada em desvantagem da espanhola:

"Tinha esta sangue português, pois era bisneta da imperatriz D. Isabel, neta do primeiro Filipe e filha do duque de Sabóia. Mas não sendo portuguesa de nascimento, não reunia tão-pouco as condições de filha, irmã, tia ou sobrinha do monarca, pelo que a nomeação violava o capítulo III das Cortes de Tomar. O grau de parentesco não justificava a escolha, mas o conde-duque que a inspirou, além de colocar uma pessoa de confiança à cabeça de um reino insubmisso, decerto contou que o governo de uma princesa estrangeira podia agradar aos Portugueses" 43.

Esta mulher saboiana, estrangeira em terra estrangeira, encontrava-se de repente a encarnar o rosto menos agradável da supremacia espanhola, ainda por cima ladeada por péssimos e malvados conselheiros.

\section{A experiência mais difícil? Do entusiasmo à condenação}

O juízo negativo sobre a actuação de Margarida não amadureceu só posteriormente, depois da sua deposição no $1 .^{\circ}$ de Dezembro de 1640 , mas foi, antes pelo contrário, o leitmotiv dos seus últimos três anos de governo. Todavia, fazendo fé em algumas fontes, não foi sequer um preconceito: em algumas, a chegada a Lisboa de uma princesa de sangue real foi acolhida até como um sinal de atenção por parte de Filipe para com o seu domínio português. A esperança suscitada pela soberana transparece por exemplo,

\footnotetext{
42 Ibidem, p. 158.

43 SERRÃO, J. V., 1979, p. 124.
} 
no incipit da História Portugueza de Manuel Severim de Faria, uma densa crónica tecida de 1610 a 1641 para celebrar «a feliz aclamação de El-Rei dom João IV» ${ }^{44}$. O manuscrito ser-nos-á de grande ajuda na reconstituição, mês a mês, do período português da Infanta.

O autor, segundo uma interpretação que foi retomada também em análises bastante recentes ${ }^{45}$, defende que o envio de Margarida de Sabóia respondia ao pedido das Cortes portuguesas de ter um membro da família real como directo interlocutor. Nas suas próprias palavras:

"Porque nas Cortes últimas pediu este reino com instância se lhe desse governador da Casa Real, querendo satisfazer em parte a esta petição, nomeou por governador e capitão general a Senhora Infante de Sabóia dona Margarida sua prima, filha dos duques de Sabóia e duquesa que foi de Mântua. Veio esta Senhora de Itália a Barcelona nas galeras...e dali a Madrid, acompanhada de cem grandes. Entrou na Corte a 11 de Novembro, S. M. a recebeu com grandes cortesias" 46.

A nomeação suscitou, na realidade, algum entusiasmo, se não por outro motivo, pelo menos em virtude da sua aparente excentricidade. A falar verdade, não era pouco habitual, para os Habsburgos de Espanha, delegarem o governo de províncias do Império em membros da sua família, nem em figuras do género feminino; o caso mais evidente é o de Isabel Clara Eugénia, filha de Filipe II e Isabel de Valois, e irmã de Catarina Micaela, que, como se sabe, governou por longo tempo os Países Baixos ${ }^{47}$. Nem sequer era a primeira vez que um Sabóia era escolhido para um cargo de alta posição internacional: existia um precedente, importante, de Manuel Felisberto (1588-1624), irmão de Margarida, que, em 1622, tinha sido proclamado vice-rei da Sićlia e que, devido à morte precoce, por doença, tinha recebido exéquias reais entre Palermo e Madrid ${ }^{48}$. Uma década mais tarde,

\footnotetext{
44 BNP, Cod. 241.

45 SERRÃO, J. V., 1979, p. 124.

46 BNP, Cod. 241, fls. 295v-296.

47 SÁNCHEZ, M., 2009.

48 RIVERO RODRÍGUEZ, M., em vias de impressão.
} 
numa fase de relativa instabilidade nas relações entre Turim e Espanha, a opção saboiana configurava-se útil e ao mesmo tempo relançava a dinastia no plano internacional.

Tenha-se em consideração, todavia, que o título de vice-rainha, atestado nos documentos oficiais espanhóis e turinenses foi, por sua vez, redimensionado na maior parte das fontes portuguesas. Como escrevem Faria e Fonseca, Margarida chegava a Portugal nas vestes de "governador e capitão-geral”, sem os explícitos atributos da soberania do rei católico. Em abono da verdade, estes foram-lhe, por sua vez, tributados: como é referido num relatório saboiano, expedido de Madrid, quando Margarida ali chegou em inícios de Novembro, "a Infanta retirou-se para a Casa do Tesouro, onde estava alojado o falecido Sereníssimo Príncipe Felisberto, e foi tratada como a própria pessoa da rainha, a qual, tendo percebido que o robe de quarto da infanta não tinha chegado, enviou-lhe um, recamado a âmbar, entre outras gentilezas» ${ }^{49}$. Àparte a cortesia entre damas, a reforçar a sua posição de primeiro plano era o próprio alojamento na residência que tinha sido do irmão vice-rei e a visita que o núncio e os embaixadores do Império, de França e de Veneza, para além de alguns dignitários espanhóis, como o cardeal Zapata, lhe fizeram no dia seguinte. Por outro lado, era preciso manifestar «quanta satisfação a Espanha sentia em receber uma tão boa e grande princesa, descendente da falecida e prudentíssima Infanta Catarina, filha do augustíssimo Filipe II». Até o conde-duque lhe chamou real, quando, depois das paragens do cortejo em Barcelona e em Alcalá, a foi esperar nos arredores de Madrid; quando ela chegou, depois das saudações formais e com um gesto de alusão ao esplêndido retrato que dela lhe deu Velázquez, Olivares «montou de imediato a cavalo e esteve sempre junto à liteira, conversando com a Sereníssima Infanta com o chapéu na mão, e como a Sereníssima Infanta lhe pedia repetidamente que se cobrisse, assim Sua Excelência encontrava sempre ocasião para estar descoberto, e de tal forma a acompanhou até ao Retiro, onde o rei a esperava». O encontro com Filipe não foi de somenos. Ela ajoelhou-se aos seus pés, o primo pediu-lhe que se levantasse, «e entrou

49 ASTo, Corte, Casa Reale, Cerimoniale, Spagna, m. 1, fasc. 3. Daqui provêm as citações que se seguem. 
com ela sozinha na carruagem por longo tempo", manifestando-lhe afecto e confiança pelas funções que lhe haviam sido atribuídas.

Também a crónica de Faria, subdividida em Relações correspondentes a anos isolados, percorre as etapas da viagem, oferecendo maiores pormenores sobre o itinerário português e apresentando os actores daquilo que se tornaria um drama. Depois das recepções em Madrid, nos primeiros dias de Dezembro de 1634, Margarida pôs-se a caminho de Portugal, acompanhada pelo marquês de la Puebla, primo do conde-duque de Olivares e nomeado lugar-tenente do governo do reino, e por «alguns gentis homens italianos e bem como dos ministros oficiais de sua Casa. Vinha também o secretário Miguel de Vasconcelos, português, por quem corria a disposição de reformador». A estas duas personagens voltaremos em breve.

O cortejo partiu para Lisboa e a infanta foi recebida em Évora com magnificência pelo bispo e pela nobreza a 18 de Novembro. "Em nome do cabido», foi saudada por "dois primeiros dignitários», um dos quais era o nobre Fernando de Melo e o outro o próprio autor da crónica, D. Manuel Severim de Faria, que se refere a si na terceira pessoa ${ }^{50}$. Testemunha ocular do facto, viu Margarida desejosa de fazer "orações” e devoções, ao estilo da tradição espanhola e das irmãs, próximas da espiritualidade franciscana. A Infanta "mostrou grande piedade e religiosidade», venerando as relíquias do Santuário do "Santo Lenho" de Vera Cruz do Alentejo - um notável apelo ao culto do Sudário, tão caro em Turim e à própria Catarina Micaela ${ }^{51}$ - e assistindo à missa no colégio local da Companhia de Jesus. O tratamento foi, sem dúvida alguma, régio: «De Almada se embarcou para Lisboa em um real bergantim que se fez para servir a pessoa de S. A. em semelhantes ocasiões. O tempo era mui chuvoso e ainda assim vieram

50 Manuel Severim de Faria (Lisboa, 1584 - Évora, 1655), filho de um funcionário régio, transferido para Évora durante a sua infância, é um importante expoente da cultura portuguesa do século xvir. Licenciado em Teologia, tomou votos sacerdotais. Em 1609 sucedeu ao tio Baltazar no cargo de cónego da cidade episcopal, desenvolvendo e cultivando notável interesse pela História, a Arqueologia, a Numismática e a Paleografia (até egípcia), todas elas disciplinas a que dedicou numerosos escritos. Autor de uma importante biografia de Luís de Camões, em 1624 publicou os Discursos Vários Políticos, nos quais propôs ao soberano transferir a sede da corte de Madrid para Lisboa, o que é um indício do ambivalente sentimento de Faria no que se refere à Coroa e à forte ligação ao seu país.

51 COZZO, P., 2006, pp. 62-73. 
buscar a S. M. muitos ministros e fidalgos» na expectativa que o tempo melhorasse 52 .

Chegada a Lisboa a 23 de Dezembro, participou de imediato numa reunião do Conselho de Estado, durante a qual emergiram provavelmente os primeiros gérmenes de dissensão nos seus confrontos. "Os marqueses, bispos e condes dizem que pois a Senhora Infanta por filha do duque de Sabóia não pode falar de vós que menos lhe pode ter a Senhoria por governadora 53 . Eram ainda poucas vozes isoladas, porém, e o clima geral era de esperança; "assim esperamos novas prosperidades», comenta Faria, e a incansável devoção da princesa parecia de bom auspício. Entre os lugares desde logo caros a Margarida na cidade, foi o mosteiro de Santo António, onde gostava de se recolher em oração e estar longamente em silêncio segundo a rígida regra das irmãs. Entre os ministros seculares, para além de D. Francisco de Melo, outrora embaixador em Génova e na Alemanha, mencionem-se D. Duarte, irmão de Diogo de Bragança, e Diogo Soares, conselheiro de Estado, amigo de Olivares e ligado por laços de família ao secretário-geral Vasconcelos; entre os eclesiásticos, predominavam os prelados das quatro dioceses maiores, ou seja, Lisboa, Coimbra, Évora e Algarve. Vasconcelos era a chave dos equilíbrios (precários) entre Lisboa e Madrid. Membro do Conselho de Estado de Portugal, em virtude da sua ligação ao conde-duque, tinha saído reforçado de uma série de atentados à sua pessoa promovidos pela aristocracia portuguesa que aspirava à autonomia ${ }^{54}$. A questão era também do conhecimento dos observadores externos. Já na primavera de 1635, Ludovico Forni, acompanhante de Margarida, referia que as responsabilidades da hemorragia financeira portuguesa eram atribuídas ao "Marquês de la Puebla e ao secretário Gasconzello [sic], a quem já tinham querido matar por três vezes» ${ }^{55}$. E não só. Visto que a situação aparecia já gravemente comprometida, constava que no prazo de dezoito meses seria enviado a Lisboa o infante de Espanha Baldassarre Carlos, com a ideia de

\footnotetext{
52 BNP, Cod. 241, fl. 296v.

53 Idem, fl. 297.

54 OLIVEIRA, A., 2002, pp. 373-405.

55 ASTo, Corte, MPRE, Lettere ministri, Spagna, m. 25, fasc. 5, c. 2/4.
} 
«reconduzir a senhora infanta para Itália numa qualquer função» ${ }^{56}$. Mas assim não aconteceu e, pelo contrário, nos meses sucessivos, Margarida pareceu conquistar um papel de maior visibilidade. É ainda Forni que nos informa que, em Junho, se projectava «trazer a princesinha de Inglaterra para Lisboa e entregá-la nas mãos da senhora Infanta D. Margarida para a consorciar, mais tarde, com o príncipe de Espanha ${ }^{57}$. O encargo de natureza puramente mulheril não teve seguimento, mas é sintomático da posição de relevo alcançada pela duquesa no seio dos Habsburgos.

Também Faria propõe uma explicação política para a escolha de Margarida como delegada da Coroa. A seu ver, estava em andamento uma cautelosa aproximação entre Filipe IV e o duque de Sabóia Vítor Amadeu I, reforçada em Janeiro daquele mesmo ano pelo nascimento de uma filha ao rei de Espanha e pelo habitual envio de felicitações por parte dos príncipes europeus ${ }^{58}$. Na realidade, ao monarca interessava manter ocupadas as tropas do duque contra os Franceses «e para isso mandou a Portugal por governador a senhora princesa Margarida, e o príncipe Tomás, que andava no exército francês, desapareceu dele e em breves dias se descobriu em Bruxelas». Ao mesmo tempo, a mulher de Tomás, príncipe de Carignano, tinha-se transferido para Milão, "onde S. M. a sustenta conforme seu estado»59. A análise não é destituída de subtileza política e enquadra bem a função do ducado subalpino no âmbito dos conflitos europeus; tem em conta também o papel desempenhado pelos membros da dinastia italiana, dispostos a servir no estrangeiro segundo as conveniências.

Da sua parte, Margarida enfrentava as suas obrigações com o empenho e a compunção solicitadas:

"Continuou no governo de Portugal a senhora princesa Margarita, administrando este cargo com grande prudência, piedade e cuidado. É mui

56 Idem.

57 Ibidem, c. 18/2, de Madrid, 30 de Junho de 1635. A princesa em causa é Henriqueta Ana (1644-1670), filha de Carlos I Stuart e de Henriqueta Maria de Bourbon, que depois casou com Filipe I d'Orleães.

58 Trata-se da Infanta Maria Ana Antónia, nascida em 1636, mas que faleceu logo de seguida.

59 BNP, Cod. 241, fl. 301v. 
contínua nos ofícios divinos, não falta nunca nos conselhos e audiências. Antes de partirem as armadas, mandou encomendar às Igrejas catedrais do reino... orações pelo bom sucesso de mar e pelas vitórias" 60 .

As preces da duquesa pelas periódicas expedições mercantis ao Brasil e por uma série de vitórias na Flandres relatadas pelo irmão Tomás levam-nos a supor que oscilava entre a vastidão atlântica do império, do qual governava uma componente fundamental, e a atenção para com os assuntos europeus nos quais ela e a sua família estavam directamente envolvidas. Mas a ausência de cartas suas desse período impede o conhecimento da sua opinião no que se refere às manobras do irmão e a uma sua eventual participação nos debates político-diplomáticos.

Ano a ano, relação a relação, a sua administração parece decorrer de modo ordinário. No início de 1636, Faria informa convencionalmente que "Continuou no governo do reino a senhora princesa Margarida com muita prudência e cuidado»61, ocupando-se, por exemplo, das fortificação da faixa costeira e dos aprestes de uma grande frota - 120 velas - destinada à defesa de Lisboa e Cascais e de futuras viagens à América do Sul. "No governo deste reino - diz-se depois para Janeiro de 1637 - continuou a senhora princesa Margarida, guardando o mesmo costume de despachar com dois conselheiros de Estado portugueses» ${ }^{62}$, ou delegando algumas funções, como parece perceber-se, a alguns conselheiros de Estado portugueses, quase a contrabalançar o desenvolvimento dos negócios particulares de D. Fernando de Toledo que se confrontava directamente com Olivares. Notar-se-á, todavia, que o tom do cronista parece agora longe do entusiasmo do primeiro biénio. Os enormes problemas do reino estavam assumindo proporções incontroláveis e não obstante o habitual "grande cuidado e zelo de S. A.", cresceram em número os «inimigos de Espanha», por causa das "esterilidades» e dos "infortúnios neste reino que está reduzido a miserável estado» 63.

\footnotetext{
60 BNP, Idem, loc.cit.

61 Ibidem, fl. 313.

62 Ibidem, fl. 319.

63 Ibidem, loc. cit.
} 
O vasto estudo de António de Oliveira sobre as revoltas portuguesas dos anos 1637-4064 dá finalmente voz também a Margarida, da qual são recordados vários provimentos assinados na época e uma série de intervenções directas nos momentos de maior crise. A Janeiro de 1637 pertence também um dos dois documentos inventariados em seu nome na Torre do Tombo ${ }^{65}$. É só uma carta, escrita em nome do rei e dirigida ao clero secular e regular de Portugal, mas é relevante e a marca de Margarida é talvez mais profunda do que poderia sugerir um texto de chancelaria. As

"alterações que há havido em alguns lugares deste reino, obrigam as prevenções, que hei mandado fazer, e porque tenho notícias que o principal fundamento de tudo são religiosos e eclesiásticos, sendo como são interessados em que os povos não consintam o real de água, e ainda que eu tenha dado diversas ordens aos prelados para que castiguem os sediciosos de sua jurisdição, não se há visto castigo nem emenda, e a sedição continua e aumenta, com que não posso deixar de acudir a apaziguar este reino".

Tratava-se, portanto, de reprimir as agitações fermentadas em ambiente religioso, e, tal como tinha sido vão o recurso «aos juizes eclesiásticos que não hão podido ou não hão querido castigar esta sedição contra seus súbditos», tornava-se necessário ameaçar com medidas mais severas. Era claro, prosseguia Margarida, que "os eclesiásticos e religiosos naturais deste reino são vassalos e súbditos meus, e como tais os que houveram entrevindo nas presentes alterações que estão sucedendo, é provável que hão cometido crime de lesa Majestade pelo juramento de fidelidade que o estado eclesiástico nos tem feito". O tom e a evocação do delito de lesa-majestade são da soberana, assim como o são as seguintes considerações:

"posto que em muitas províncias e reinos os príncipes seculares hão executado penas capitais contra as pessoas eclesiásticas que hão cometido

64 OliveirA, A., 2002, passim; veja-se também OLIVEIRA, A., 2008, pp. 361-366.

65 ANTT, Armário Jesuítico, mç. 29, n. 73, Janeiro de 1637. O outro documento é uma licença concedida pela duquesa ao religioso Manuel Pinto Ribeiro Teixeira para se deslocar a Espanha (Idem, Manuscritos da Livraria, n. 168, doc. 58, fl. 173). 
este crime, sem preceder de graduação nem outro juízo da Igreja pela autoridade que a Providência do direito natural e das leis positivas tem dado à República política, para se manter e conservar por si mesma, considerando que não pode haver seguridade nem permanecer se absolutamente ficara dependente da jurisdição eclesiástica, com o qual poderá mandar proceder logo contra os eclesiásticos culpados nesta sedição, dando-lhes o castigo que merece seu alvorotamento."

A linguagem, com as referências elevadas ao direito natural, às leis positivas e à República política, remete para a tratadística jurídico-filosófica de tradição bodiniana e prefigura o forte desencontro jurisdicional entre a Igreja e muitas coroas europeias. Agitando o poder da tradição régia e o espectro da roda perante os clérigos «incorrigíveis», Margarida e os seus conselheiros esperavam provavelmente incutir-lhes temor, bem como ao povo prestes a sublevar-se.

O aviso "contra liberdade eclesiástica" - assim está escrito ao alto, na margem do documento - caía, na verdade, em saco roto. Em Janeiro de 1629, Urbano VIII tinha concedido ao monarca de Espanha a faculdade de levantar um subsídio de 2000 escudos em seis anos para a «defesa da católica religião» nos reinos de Portugal e Algarve e o «aumento do património de Cristo»66; todavia, a tensão e o agravamento fiscal eram tais, que tornavam intolerável qualquer pedido. E como salientou autorizadamente António Manuel Hespanha ${ }^{67}$, o clero foi o primeiro motor do protesto: a corrente regalista predominante em Madrid acabara por estimular o movimento autonomista nas fileiras do clero e da sociedade portuguesa.

Margarida teve efectivamente um papel determinante na tentativa de repressão dessa efervescência. Como informa Oliveira, logo em Janeiro de 1637 recebeu de Madrid a ordem de recolher em segredo, mantendo o anonimato dos informadores, os nomes dos principais responsáveis dos levantamentos, de modo a transmiti-los à capital espanhola quanto antes ${ }^{68}$.

\footnotetext{
66 Cópia do breve pontifício em anexo, idem.

67 HESPANHA, A. M., 1986, I, p. 436.

68 OLIVEIRA, A., 2002, p. 587.
} 
Foi sempre ela a exibir alternativamente rigor e clemência com os inquiridos nas delicadas negociações com a nobreza de Évora em busca de perdão ${ }^{69}$. Mas «O tributo do papel selado», isto é, um novo imposto lançado naquela delicada circunstância, assim como "O real de água" que atingia a venda e o consumo do vinho e da carne, não puderam senão suscitar o descontentamento colectivo: "era tudo erro, tudo confusão: o povo se apelidava [...] e sem ordem nem concerto o povo dispunha e executava", comenta Faria com amargura ${ }^{70}$. Interveio D. Diogo de Castro para reprimir a revolta, mas agora "quase todo o Alentejo, o reino do Algarve, alguns lugares de Beira a exemplo de Évora sucessivamente se foram levantando contra os tributos do real de água» ${ }^{71}$. Enquanto Olivares tentava organizar um exército de ocupação para enviar para Portugal, Évora e os arredores acalmaram em Setembro, mas a chama estava agora acesa por todo o lado.

Na Historia Portugueza, o papel de Margarida vai obscurecendo pouco a pouco. Aí, não se dá conta das suas reacções à morte do duque de Mântua, Carlos I Gonzaga Nevers - que também é mencionada ${ }^{72}$ e que abria alguma esperança à sucessão da filha Maria - nem se volta ao tópico da prudência e da religiosidade da infanta, agora em uníssono com o inimigo espanhol. A crónica de 1638 inicia-se do seguinte modo: "Neste ano estava no governo de Portugal a princesa Margarida duquesa de Mântua»73, e prossegue com a narração das tensões internas. A de 1639 é ainda mais lacónica: "Esteve o governo deste reino na princesa Margarida duquesa de Mântua, com que acabou o segundo triénio» ${ }^{74}$. Parece, a bem dizer, um conto ao contrário, uma etapa necessário para o clímax da narrativa, que tem o seu fulcro nos acontecimentos do primeiro de Dezembro de 1640, antecipados em tom redentor: "Entramos a escrever o fatal ano de 1640 tão decantado dos prognósticos e profecias de Portugal» ${ }^{75}$.

\footnotetext{
${ }^{69}$ Idem, p. 590.

70 BNP, Cod. 241, fl. 321v.

${ }^{71}$ Idem, fl. 322.

72 Ibidem, fl. 327v. O Duque morreu a 22 de Setembro de 1637.

73 Ibidem, fl. 329.

74 Ibidem, fl. 337.

75 Ibidem, fl. 345.
} 
Não obstante as últimas tentativas de mediação operadas pela infanta que no mês de Maio de 1639 tinha visitado Évora para captar a simpatia da nobreza citadina ${ }^{76}$ - a sua capacidade de intervenção é agora nula e, de qualquer modo, subordinada ao desencontro final entre "castelhanos" e "fidalgos mal contentes» ${ }^{77}$. Ela própria deve-se ter apercebido da precipitação dos acontecimentos. Já em 1638 tinha pedido várias vezes a Filipe IV para a fazer regressar a Itália, aduzindo como motivação um agravamento do seu estado de saúde, comprometido pelo cansaço e pelo clima ${ }^{78}$. Protestos vãos, como vã tinha sido a tentativa de pôr fim à rivalidade no interior do Conselho Português entre o almirante da frota D. Fradique de Toledo, que, de resto, jamais a tinha estimado ${ }^{79}$, e o secretário Ruiz de Escaray ${ }^{80}$.

A tentativa de apresentar o governo de Margarida e, por conseguinte, da Espanha, como sólido e benquisto, apesar da rebelião de poucos, não funcionou. Os apoiantes dos Braganças, socialmente transversais mas concentrados sobretudo nas camadas mais elevadas da aristocracia nacional, tinham ganho cada vez maior consenso, como parecia ter preconizado Filipe IV ao entregar algumas instruções secretas à infanta no momento da sua nomeação: "O duque de Bragança é a primeira pessoa daquele reino... e é muito conveniente que o trate de modo que se veja a consideração em que tenho a sua pessoa 81 . Todavia, apesar dos conselhos adequados, a infanta «tanto em 1634... como mais tarde, em 1639, já pouco firme no poder, não soube, ou não pôde, como parece mais verosímil, resolver em seu favor a maior questão dos homens, a das honras e preeminências» 82 . A

76 Ibidem, fl. $337 \mathrm{v}$.

77 Ibidem, fls. 350-350v, onde estão enumerados muitos nobres à cabeça do protesto.

78 AGS, Estados pequeños de Italia, maço 3840, fasc. 78, cc. 221 e 222. No dia 26 de Agosto de 1638, o Conselho de Estado, composto por Olivares, pelo cardeal Borgia e pelos condes de Oñate, Santa Cruz, Castrillo, Villahermosa e Villafranca, discutiu a "proposta que a princesa Margarida fez de regressar a Italia, com a desculpa última que agora antepõe da máxima falta de saúde com que se encontra em Lisboa, pela qual teme morrer de repente». Foi decidido, todavia, não poder dar-lhe autorização, dada a instabilidade da situação portuguesa.

79 Veja-se uma sua queixa contra a incapacidade de governar da Infanta in AGS, Estado Portugal, IV, legajo 2614, cc. não numeradas, 2 de Março de 1635.

80 SCHAUB, J.-F., 2001, pp. 183-186.

81 Cit. em OliveirA, A., 2002, p. 691 (em Castelhano no texto original).

82 Ibidem, p. 692. 
inevitável cisão entre a duquesa italiana e a sociedade portuguesa torna-se tanto mais profunda se confrontada com a aparente harmonia exibida pelas partes por ocasião de uma parada militar realizada em Lisboa a 8 de Abril de 1639, dia do trigésimo quatro aniversário do rei.

Então, segundo o anónimo redactor de um discurso comemorativo na imprensa ${ }^{83}$, desfilaram diante de Margarida os corpos escolhidos do exército ibérico, comandados por oficiais espanhóis e portugueses em grande uniforme - «don Fernando Martinez Mascarenas... con armas dorada, brunida y plumas blancas»; "don Juan de Acosta, en caballo castaño y silla carmesi y oro", e assim por diante - e depois da infantaria e da cavalaria, foi a vez da parada das damas e cavaleiros da cidade, da corte e do país. Entre as primeiras, conduzidas pela camareira-mor, distinguiam-se damas nobres espanholas, portuguesas e ainda italianas: a "marquesa de Villanueva de Cardeñoso, doña Casilda Luyando, doña Maria Margarida Menina, condesa de la Vastida» e também "las señoras doña Vitoria Margarita Solara y doña Violante Viscondi, y doña Ana Mala Espina,...doña Barbora Palabesino, doña Costança Landian, y doña Francisca Luyando». O grupo de damas merecia um estudo mais aprofundado, mas, devido às ligações da vice-rainha aos estados italianos, é oportuno evidenciar a presença de membros de famílias filo-espanholas genovesas (Pallavicino), lombardas (Visconti, Landiano), piemontesas (la Solaro) ou tosco-emilianas (Malaspina). Todas pareciam contritas "debaxo de vestidos negros, que S. A. no les permite traer otra color, aunque este dia dispenso (por los años de Su Magestad) en mangas y petos bordados de plata y oro, y joyas de diamantes y perlas». O preto das roupas imposto por Margarida às damas da corte, mais do que gosto contemporâneo e alusivo à condição de viuvez da regente, remete uma vez mais para a herança materna e para a moda imposta em Turim nos finais de Quinhentos ${ }^{84}$ : talvez um outro sinal da distância, também cultural, entre a duquesa e o seu domínio.

\footnotetext{
83 BNM, ms. 2370, R/25149 (cit. também ibidem, p. 709). Devo a Mercedes Simal, a quem agradeço, a reprodução digital do texto. Deste provêm as citações que se seguem.

84 VARALLO, F., em vias de impressão.
} 
O objectivo da revista de armas era o de recordar, a despeito dos seus émulos e detractores, que não era só no coração da Espanha que se manifestava o poderio da monarquia, mas também «en la fronteras y puertos» do seu imenso império, «siendo el reyno de Portugal uno de lo mas principales que ilustra y enriqueze la diadema de sus reales». O seu governo, era repetido de maneira explícita, tinha sido confiado por Filipe a «su prima la señora Infanta Margarita» na certeza de que, não obstante as "no pequeñas dificultades» que teria podido encontrar, as suas «inteligencia y competencias entre los ministros de las dos coronas» teriam sabido fazer-lhes frente. A representante da coroa de Habsburgo assistiu ao evento do alto do conjunto dos seus títulos completos - "la Serenisima Infante Margarita de Saboya, duquesa de Mantua y Monferrato, virrei de las coronas y conquistas de Portugal en las cuatro partes del mundo, capitan general de sus armas y de la Castilla en aquellos reynos» - mas nunca como naquele momento a prosopopeia dos seus cargos tinha sido vazia e inutilmente retumbante.

\section{A deposição e o regresso a Espanha}

O silêncio dos documentos turinenses sobre o fracasso de Margarida em Portugal desperta alguma admiração, mas pode ser talvez atribuído às desordens internas causadas pela guerra civil que opôs a regente Cristina aos cunhados Tomás e Maurício, e com eles amplos estratos da aristocracia e das camadas dirigentes urbanas. As relações diplomáticas com a Espanha interrompem-se em $1638^{85}$ e retomam o regime pleno só nos anos cinquenta, deixando em silêncio o fatídico 1640 e os anos de retiro da infanta em Madrid. Não se exclui que a antipatia de Cristina por Margarida, Maria Gonzaga e os seus sentimentos filo-espanhóis ${ }^{86}$ tenha deteriorado a já

85 ASTo, Corte, MPRE, Lettere ministri, Spagna, mm. 20, 26 e 27.

86 Idem, m. 25, fasc. 3, 24 de Novembro de 1637. Assim escreveu Cristina a Giovanni Francesco Gandolfo, bispo de Alba e ex-embaixador de Sabóia em Espanha, a propósito dos movimentos das tropas espanholas no Monferrato, exprimindo-se contra a vontade de intervir: "pouco nos convida o ânimo da princesa de Mântua para com esta casa, sabendo-se muito bem que ela não corresponde àquelas rectas intenções que serviriam para nos provar que à obrigação do sangue quisesse acrescentar uma igual sinceridade de afecto». 
escassa atenção reservada pelos observadores turinenses à aventura extra-territorial da infanta. Nem é impossível que, passando em resenha outras fontes, não se encontre algum comentário venenoso da princesa Bourbon sobre a débacle da cunhada. A fazê-lo pressagiar, considerem-se, por exemplo, as ácidas considerações proporcionadas pelo bispo Gandolfo a Madame Real no momento fulcral dos tumultos portugueses de 1638 e do ousado projecto de casamento entre Maria e o tio cardeal Maurício:

"Não creio que haja fundamento intencional por parte dos espanhóis no dito casamento, se bem que seja proposta da senhora Infanta Margarida, a qual vendo-se revogada do governo de Portugal, deve andar a propor coisas com as quais ela pensa poder sustentar-se. E os ministros régios, para a despedirem de lá, mostram porventura aplaudir a dita proposta porque, logo que chegue a Itália, se bem que aí encontre o obstáculo dos franceses e dos venezianos, pouco lhes importa conquanto que a mandem para lá»87.

De facto, os comentários sobre a sua deposição são quase nulos (na historiografia saboiana o caso pode ter despertado algum embaraço) ou palidamente artificiais. Glosando Quazza, a princesa de Sabóia comportou-se em Portugal o melhor possível e enfrentou com coragem até os rebeldes que a expulsaram, "com os olhos relampejando de desdém»88. Mas não se conhecem, por enquanto, comentários directos mais credíveis sobre o seu ponto de vista. E, contudo, o acontecimento foi impressionante, icástico e, se quisermos, premonitório de deposições bem mais sanguinárias no futuro imediato (aludo, naturalmente, à desentronização de Carlos I Stuart). $\mathrm{Na}$ realidade, a Restauração, para a história de Portugal, coincide com a conquista da independência face à Espanha e não tem nada a ver com o restabelecimento das monarquias nacionais perante a desagregação do ulterior império napoleónico.

Voltemos ao vívido relato de Manuel Severim de Faria, fonte preciosa por variadas reconstituições sucessivas. No $1 .^{\circ}$ de Dezembro de 1640 , ao

\footnotetext{
87 Ibidem, fasc. 7, c. 14/4, Monsenhor Gandolfo a Cristina, de Alba, 12 de Maio de 1638. 88 QUAZZA, R., 1930, p. 216.
} 
grito "Liberdade! Liberdade!", os restauradores ou conjurados, como foram chamados, entraram armados nas salas do palácio real de Lisboa, «e uns na secretaria, outros na sala dos tudescos, outros no quarto da duquesa de Mântua, e outros... às portas do Paço para que o secretário não pudesse fugir»89. Este último, Miguel de Vasconcelos, foi rapidamente capturado e morto. A vice-rainha encontrou-se a enfrentar um punhado de homens enfurecidos e de ideias claras: a sua câmara foi invadida, por, entre outros, António de Saldanha, Luís de Melo, António de Melo, Fernão Teles, Gonçalo de Távora, D. António de Almada e D. Carlos de Noronha, os quais

"chegando todos diante da princesa entendendo ela a morte do secretário, disse que gostava o que estava feito, que por estar bem feito S. M. perdoaria tudo, mas António de Saldanha lhe respondeu que havia outra Majestade, a do rei dom João o $4^{\circ}$ "90.

Refém dos rebeldes, Margarida ficou sob guarda na residência do marquês de la Puebla por algumas semanas, acusada por Olivares de ser em boa medida responsável do desastre espanhol em Portugal e impossibilitada de regressar a Madrid ${ }^{91}$. Entretanto, enquanto o país se libertava da representante da monarquia imperial (jamais chamada vice-rainha e nem sequer regente), preparava-se para acolher a sua verdadeira rainha - paradoxalmente uma espanhola, Luísa de Gusmão, filha do $8^{\circ}$ duque de Medina Sidónia, que tinha sido dada em casamento a D. João de Bragança sob desígnio de Olivares $^{92}$-, embarcando-a num navio em direcção a Lisboa ${ }^{93}$. E assim, com o regozijo pela libertação do reino, encerram-se as páginas da crónica.

Os acontecimentos que dizem respeito ao regresso de Margarida de Sabóia a Espanha e a sua plena reintegração na corte de Madrid permanecem algo misteriosos, mas estão, sem dúvida, ligados ao declínio e à queda em desgraça de Gaspar de Gusmão, conde-duque de Olivares, sobre quem John

\footnotetext{
89 BNP, Cod. 241, fl. 351v.

90 Idem, ff. $353 \mathrm{v}-354$.

${ }^{91}$ SCHAUB, J.-F., 2001, p. 186.

92 OLIVEIRA, A., p. 691.

93 BNP, Cod. 241, fl. 365v.
} 
Elliott escreveu páginas exemplares ${ }^{94}$. O historiador britânico não faz menção a Margarida, mas detém-se longamente na importância da guerra da sucessão de Mântua e do Monferrato, no confronto pessoal e político entre o valido e Richelieu, assim como no desastre português ao determinar o fim inglório do primeiro ${ }^{95}$. Na libelística hostil, pelo contrário, a duquesa encontra um lugar nada secundário. Se a rainha Isabel de Bourbon e o astro nascente de D. Luís Méndez de Haro tinham posto em movimento a máquina da sua ruína, juntamente com a crise catalã, a inflação e uma série de derrotas militares na Europa, "el tercer personage que pareciò en esta escena para ocasionar el catastrofe de la ruina del Conde-Duque fue la señora Infanta doña Margarita de Saboya, duquesa de Mantua» ${ }^{96}$.

Quem escreve é António Valladares, autor de um Seminario erudito destinado à nobreza madrilena, no qual fez incluir um texto intitulado Caida de su privanza y muerte del Conde-duque de Olivares, atribuindo-o a Francisco de Quevedo, sem, todavia, afastar a hipótese de que se devia, na realidade, à pena do "marquês da Grana Carretto, que foi embaixador de Viena na nossa corte» 97 . Que o relato pudesse ser do marquês Carreto de Grana, expoente da nobreza imperial activa no Piemonte, abre cenários que estão fora deste estudo, mas explicaria o interesse específico pela princesa da Casa de Sabóia. Na reconstrução melodramática proporcionada pela memória - e, não o sabemos, quão reelaborada por Valladares - Margarida encontrava-se há mais de um ano prisioneira em Ocaña, no palácio dos marqueses Cardenas, "por ordem do conde-duque para que não tivesse meio de comunicar com o rei»98. Todavia, "movida de las violencias de la hambre», uma vez que Gusmão não lhe fazia a entrega nem sequer da pensão atribuída pelo soberano, rebelou-se contra essa extrema humilhação e conseguiu fugir para se deter em segredo em Madrid. "A Infanta partiu de Ocaña não como

94 ELLIOTT, J., 1991, pp. 180 e sgts.

95 Idem, pp. 105-135, 179 e sgts.

96 Idem, pp. 105-135, 179 e sgts.

97 Idem, p. 1.

98 Ibidem, p. 22. Sobre a estada forçada em Ocaña, cf. também VALLADARES, R., 2008, p. 51. É de assinalar que o lugar estava, já havia tempo, ligado à família real e que Carlos V o tinha escolhido para ali educar a filhas (SANCHEZ MOLERO, J. L., em vias de impressão). 
pessoa livre, mas como fugitiva» e quando chegou à capital, "maltratada pelo frio e pela chuva, e com as damas na sua própria carruagem», Olivares, no cume da sobranceria e pronunciando palavras «de grande desprezo» por ela, fê-la instalar-se, com as suas acompanhantes, em «três miseráveis apartamentos fora do Palácio real, com as paredes despojadas» 99.

Porquê tanta raiva e desprezo por quem, oito anos antes, tinha acolhido de cabeça descoberta numa tão diferente entrada na cidade? "Las causas de la adversión que el animo del Conde-Duque tiene a esta princesa - prossegue o autor do libelo - son muchas, y la mayor parte de ellas escondidas o notorias a pocos; mas yo he tenido la felicidad de penetrarla todas ${ }^{100}$. A primeira razão derivava do ódio amadurecido "contra todos os príncipes da Casa de Sabóia», e contra o duque de Lerma, de quem Olivares se apresentava como imediato sucessor nos favores exclusivos do rei, «sendo assaz duro manifestar humildade e reverência a príncipes de sangue real». Tratar-se-ia de inveja, em suma, aguçada pela posição alcançada por Margarida: "a segunda causa foi o facto que Sua Alteza tivesse ocupado durante sete anos o cargo de vice-rainha de Portugal, se bem que, na realidade, mais como escrava da vontade do conde-duque, do que como governante efectiva»101. Os verdadeiros soberanos eram o marquês de la Puebla e Vasconcelos, mas a infanta, consciente das suas falsidades, tinha apresentado frequentes queixas ao conde-duque, sem que fossem por ele tomadas medidas adequadas para o restabelecimento da sua autoridade. Então, Margarida mudou de estratégia "y en lugar de escribir al Conde-Duque, inmediatamente escribio su quejas al Rey en multiplicadas cartas». Seria útil encontrar em Simancas estas missivas, que confirmariam o carácter decidido e altivo da infanta. O certo é que Olivares, sentindo-se ultrapassado pela vice-rainha, ofendeu-se profundamente até «tenerla siempre por su enemiga capital» ${ }^{102}$. E daí, a «sua saída de Portugal (que teve algo de milagroso»103), a reclusão em Ocaña e todo o esforço de Gusmão para a impedir de rever

\footnotetext{
99 VALLADARES, A., 1738, III, p. 22 (as citações estão em Castelhano no texto original).

100 Idem, p. 23.

101 Ibidem (em Castelhano no texto original).

102 Ibidem.

103 Ibidem, p. 30.
} 
o rei seu primo. E daí também o início do fim do potente valido: regressada penosamente a Madrid, "a senhora Infanta chegou à corte nos mesmos dias em que o rei começava a abrir os olhos» ${ }^{104}$. Como tinha sucedido em 1634, foi acolhida com particular calor pela rainha Isabel, a quem Margarida contou o torvelinho dos acontecimentos do seu governo em Portugal, recebendo, por sua vez, numerosos sinais de gratidão do casal real.

A fonte é, decerto, parcial e toda ela orientada para desacreditar Olivares. Todavia, sem forçar demasiado as interpretações, fica o facto de que "a fatal máquina" que ele tinha construído para controlar Portugal tinha-se virado contra si pela complexidade das contingências históricas e pela tomada de posição da princesa de Sabóia que, se bem que refreada, não tinha perdido a têmpera de mulher de poder. De resto, a benevolência de Filipe nos seus encontros testemunha que, do ponto de vista espanhol, não era ela que tinha sido julgada responsável pelo fracasso, mas antes o conde-duque com os seus protegidos. Uma última imagem da queda de Olivares merece ser relatada: expulso o valido da corte, no domingo 18 de Janeiro de 1643 ,

"na segunda-feira, o Rei, a Rainha, o Príncipe, a Infanta e a duquesa de Mântua saíram em público para se dirigirem ao convento de Las Descalzas Reales. Foram seguidos por uma multidão numerosa, que gritava: "Vivam os soberanos e o Príncipe, nossos Senhores, e morra o mau governo!”105.

A estreita proximidade com o monarca e com a sua família permitiram a Margarida passar o resto da vida ocupando-se - com o pragmatismo que a caracterizava e com uma certa obsessão - com a recuperação do seu dote e do de sua mãe Catarina Micaela, perdidos na voragem da dívida espanhola ${ }^{106}$. Por outro lado, reaproximando-se prudentemente da cunhada Cristina, que, no fim da guerra civil do Piemonte ordenou que lhe fosse paga uma pensão adequada107, a duquesa não deixou escapar uma última

104 Ibidem (em Castelhano no texto original).

105 Ibidem, p. 52 (em Castelhano no texto original).

106 RAVIOLA, B. A., em vias de impressão ${ }^{1}$.

107 ASTo, Corte, Paesi, Monferrato, Doti dell'Infanta Margherita, m. 12, fasc. 5, ordem de Madame Real de 5 de Dezembro de 1642 para que se atribuísse a Margarida a soma anual de 12.000 liras. 
viagem a Itália para rever a filha e estabelecer-se, assim, em Vigevano ${ }^{108}$. A meta final, se bem que ainda não se encontrem disponíveis os necessários cotejos documentais, era a cidade lombarda em que a irmã Maria Apolónia era madre superiora num convento de Carmelitas ${ }^{109}$.

Não é oportuno voltar, neste momento, às últimas vontades de Margarida, que já examinei noutro lugar e defini como uma espécie de testamento político $^{110}$. O que vale a pena sublinhar como conclusão deste estudo é talvez, e uma vez mais, a extraordinária parábola de vida e morte desta infanta ítalo-espanhola. As suas três vidas de princesa, duquesa e vice-rainha - num singular crescendo de honras e desgostos - permitem destacar as potencialidades garantidas às dinastias italianas pelos seus laços com as principais monarquias da Europa ${ }^{111}$ e apanhar, através da princesa Sabóia, le fil rouge dos vínculos com Portugal que, com andamento cársico, da Idade Média à Contemporaneidade, reemerge para tecer um desenho fascinante. A história de Margarida adere ao fio durante um lance breve e incómodo, mas altamente significativo e decerto digno de uma reavaliação em chave de leitura de escala europeia, mais do que de uma severa e expedita remoção historiográfica.

\section{Fontes e estudos}

\section{Fontes manuscritas}

Archivo General de Simancas (AGS)

Estados pequeños de Italia, legajo 3830

Estados pequeños de Italia, legajo 3835

Estado Portugal, IV, legajo 2614

\footnotetext{
108 TAMALIO, R., online.

109 RAVIOLA, B. A., 2012, pp. 887-910.

110 RAVIOLA, B. A., 2008, pp. 340-341.

111 SPAGNOLETTI, A., 2003, pp. 159 e sgts.
} 


\section{Archivio di Stato di Torino (ASTo)}

Real Casa, Lettere di principi, duchi e sovrani:

Lettere dell'Infanta Margherita di Savoia, mazzo (m.) 6

\section{Materie politiche per rapporto all'Interno}

Cerimoniale, Spagna, m. 1, fasc. 3, 7 novembre 1634, Relatione dell'Entrata della Serenissima Infanta Margarita di Savoia, duchessa vedova di Mantova, negli Stati di S.M. Cattolica, e del ricevimento fattogli in Barcellona, Alcalà e Madrid. Doppo di che andò in Portogallo per vice-regina.

Materie politiche per rapporto all'Estero (MPRE):

Lettere ministri, Spagna, m. 9

Lettere ministri, Spagna, m. 20

Lettere ministri, Spagna, m. 25

Lettere ministri, Spagna, m. 26

Lettere ministri, Spagna, m. 27

Paesi, Monferrato, Doti dell'Infanta Margherita, m. 14, fasc. 5

\section{Archivo General de Palacio (AGP), Patrimonio Nacional (PM):}

Histórica, caja 117, Recepciones y hospedajes de soberanos y principes extrangeros, Princesa Margarita de Saboya en 1634

\section{Arquivos Nacionais da Torre do Tombo (ANTT)}

Armário Jesuítico, mç. 29, n. 73, Copia da carta do (rei d. Filipe III), para os bispos e prelados regulares do reino de Portugal

Manuscritos da livraria, n. 168, doc. 58, Petiçao do padre Manoel Pinto Ribeira Texeira à duqueza de Manta, quando governava Portugal; com o despacho de la mesma prinzesa, f. 173

\section{Biblioteca Nacional de Madrid (BNM)}

R/ 25149, Discurso aiustado con la muestra que bizo de la gente de guerra la Ciudad de Lisboa a S.A. la Serenisima Infante Margarita de Saboya, duquesa de Mantua y Monferrato, virrei de las coronas y conquistas de Portugal, en las cuatro partes del mundo, capitan general de sus armas y de las Castilla en aquellos reynos, en 8 d'este mes de Abril año de 639 .

\section{Biblioteca Nacional de Portugal (BNP)}

Cod. 241, Manuel Severim de Faria, Historia Portugueza e de outras Provincias de occidente desde o anno de 1610 até o de 1640 da felice acclamação de el Rey dom João IV (microfilm n. 1441) 


\section{Fontes impressas e reportórios}

Diccionario bibliographico portuguez (1862), coord. Innocencio Francisco da Silva

Diccionario enciclopedico U.T.E.H.A. (1953), Ciudad de Mexico: Unión Tipográfica Editorial Hispano Americana

Enciclopédia Luso-brasileira de cultura Verbo, vol. 18, Lisboa-Saõ Paulo: Ediçaõ Século XXII

FONSECA, Francisco de, 1728, Evora gloriosa. Epilogo dos quarto Tomos da Evora illustrada que compoz o R. P. M. Manoel Fialbo da Companhia de Jesu, escrita, acrescentada e amplificada pello P. Francisco da Fonseca da mesma Companhia, dedicata ao eminentissimo e reverendissimo Senhor Alvaro do titulo de San Bartholomeo in Insula cardenal Cienfuegos, comprotector da Germania, arcebispo e senhor de Monreal, conselbero de S. M. C. e C. e seo plenipotenciario à Santa Sè Apostolica, Roma: na oficina Komarekiana

Grande Enciclopédia portuguesa e brasileira, s.d., Lisboa-Rio de Janeiro

MANNO, Antonio, Il Patriziato subalpino. Notizie di fatto storiche, genealogiche ed araldiche desunte da documenti, Firenze, Civelli, 1896-1905, 2 voll. a stampa e 27 dattiloscritti, ora consultabile on-line all'indirizzo: http:// www.vivant.it

\section{Estudos}

BELLONCI, Maria, 1963 (I ed. 1947), Segreti dei Gonzaga, Milano: Mondadori

BESUTTI, Paola, 1999, "Il matrimonio dell'infanta Margherita: le feste a Mantova", in Politica e cultura nell'età di Carlo Emanuele I. Torino, Parigi, Madrid, a cura di M. Masoero, S. Mamino, C. Rosso, Firenze: Olschki, pp. 491-506

COSANDEY, Fanny, 2000, La reine de France, symbole et pouvoir, Paris: Gallimard

COSANDEY, Fanny, 2008, "De la loi salique à la régence. Le parcours singulier du pouvoir des reines”, in VARALLO, F. (ed.), In assenza del re. Le reggenti dal XIV al XVII secolo (Piemonte ed Europa), Firenze: Olschki, pp. 183-197.

COZZO, Paolo, 2006, La geografia celeste dei duchi di Savoia. Religione, devozione e sacralità in uno Stato di età moderna (secc. XVI-XVII), Bologna: il Mulino

CRAVERI, Benedetta, 2008 (I ed. 2005), Amanti e regine. Il potere delle donne, Milano: Adelphi

DEL RÍO BARREDO, Maria José, 2006, "El viaje de los príncipes de Saboya a la corte de Felipe III (1603-1606), in L'affermarsi della corte sabauda. Dinastie, poteri, élites in Piemonte e Savoia fra tardo medioevo e prima età moderna, a cura di P. Bianchi e L. C. Gentile, Torino: Zamorani, pp. 407-434

GIACHINO, Luisella, 2011, "Margherite evangeliche» e "donne di diamante» nei Panegirici di Emanuele Tesauro", in Predicare nel Seicento, a cura di M. L. Doglio e C. Delcorno. Bologna: il Mulino, pp. 73-104.

HESPANHA, António Manuel, 1986, As vésperas do Leviathan. Instituições e Poder politico. Portugal - sec. XVII, 2 voll., Lisboa: s.n.t.

LABRADOR ARROYO, Félix, 2009, La Casa Real en Portugal (1580-1621), Madrid: Ediciones Polifemo

MERLIN, Pierpaolo, 1991, Tra guerre e tornei. La corte sabauda nell'età di Carlo Emanuele I, Torino: SEI 
MERLIN, Pierpaolo, 2008, "Caterina d'Asburgo e l'influsso spagnolo", in VARALLO F. (ed.), In assenza del re. Le reggenti dal XIV al XVII secolo (Piemonte ed Europa), Firenze: Olschki, pp. 209-234.

MONGIANO, Elisa, in corso di stampa, "Quale dote per un'Infanta di Spagna? Il contratto di matrimonio di Caterina d'Austria”, in RAVIOLA, B. A., VARALLO, F. (ed.), L'Infanta. Caterina d'Austria duchessa di Savoia (1567-1597), Atti del convegno internazionale di studi, Torino, 30 settembre -2 ottobre 2009, Roma: Carocci

MOSTACCIO, Silvia, 1999, "Le sante di corte", in M. Masoero, S. Mamino, C. Rosso (ed.), Politica e cultura nell'età di Carlo Emanuele I. Torino, Parigi, Madrid, Firenze: Olschki, pp. 461-474

NALDI, Carlo, GIANASSO, Elena, ROGGERO, Costanza (ed.), 2011, Maria Giovanna Battista di Savoia Nemours. Memorie della reggenza, Torino: Centro Studi Piemontesi

Oliveira, António de, 2002, Movimento Sociais e Poder em Portugal no Século XVII, Coimbra: Instituto de História Económica e Social, Faculdade de Letras

OLIVEIRA, António de, 2008, Dom Felipe III, Lisboa: Temas e Debates

ORESKO, Robert, 2004, "Maria Giovanna Battista of Savoy-Nemours (1644-1724): daughter, consort and regent of Savoy", in CAMPBELL ORR, C. (ed.), Queenship in Europe, 1660-1815. The Role of the Consort, Cambridge: Cambridge University Press, pp. 16-55

PAOLI, Maria Pia, 2008, Di madre in figlio: per una storia dell'educazione alla corte dei Medici, in Annali di storia di Firenze, III, Firenze University Press, pp. 65-145

PARUSSO, Giulio, 2007, "La beata Margherita di Savoia", in MAESTRI, R. (ed.), L'arrivo in Monferrato dei Paleologi di Bisanzio (1306-2006), Alessandria: Circolo culturale "I marchesi del Monferrato", pp. 89-95

QUAZZA, Romolo, 1930, Margherita di Savoia, duchessa di Mantova e viceregina di Portogallo, Torino: Paravia

RAVIOLA, Blythe Alice, 2008, "Il filo di Anna. La marchesa d'Alençon, Margherita Paleologo e Margherita di Savoia-Gonzaga fra antichi stati italiani ed Europa", in VARALLO, F. (ed), In assenza del re. Le reggenti nei secoli XVI-XVII (Piemonte ed Europa), Firenze: Olschki, pp. 317-341

RAVIOLA, Blythe Alice, 2012, "Venerabili figlie: Maria Apollonia e Francesca Caterina di Savoia, monache francescane, fra la corte di Torino e gli interessi di Madrid (1594-1656)", in MARTínez millán, J; RIVERO RODRÍGUEZ, M.; VERSTEEGEN, G. (eds.), La Corte en Europa: Política y Religión (siglos XVI-XVIII), Atti del Congreso internacional de la red "The Court Studies", Madrid, 13-16 diciembre de 2010, 3 Vols., Madrid, Editorial Polifemo, vol. II, pp. 887-910.

RAVIOLA, Blythe Alice, in corso di stampa ${ }^{1}$, "Hija de tal madre». Margherita di Savoia Gonzaga e il recupero delle sue doti”, in RAVIOLA, B. A., VARALlO, F. (ed.), L'Infanta. Caterina d'Austria duchessa di Savoia (1567-1597), Atti del convegno internazionale di studi, Torino, 30 settembre -2 ottobre 2009, Roma: Carocci

RAVIOLA, Blythe Alice, in corso di stampa ${ }^{2}$, The Three lives of Margherita of Savoy, duchess of Mantua and vicereine of Portugal, in CRUZ, A. J., GALLI STAMPINO, M. (ed.), Habsburgs Rulers Women in Early Modern Europe, Chicago: Chicago University Press

Rivero Rodríguez, M., VERSTEEgen, G. (eds.), La Corte en Europa: Política y Religión (siglos XVI-XVIII), Atti del Congreso internacional de la red "The Court Studies", Madrid, 13-16 diciembre de 2010, 3 vols., Madrid, Editorial Polifemo, Vol. II, pp. 887-910.

RIVERO RODRÍGUEZ, Manuel, in corso di stampa, "La casa del príncipe Filiberto de Saboya", in RAVIOLA, B. A., VARALlO, F. (ed.), L'Infanta. Caterina d'Austria duchessa di Savoia (1567-1597), Atti del convegno internazionale di studi, Torino, 30 settembre - 2 ottobre 2009, Roma: Carocci

ROSSO, Claudio, 2008, "Le due Cristine: Madama Reale fra agiografia e leggenda nera", in VARALLO, F. (ed), In assenza del re. Le reggenti nei secoli XVI-XVII (Piemonte ed Europa), Firenze: Olschki, pp. 367-392 
SANCHEZ-MOLERO, José Luis, "L'educazione "devozionale» delle Infante", in B. A. Raviola, F. Varallo (ed.), L'Infanta. Caterina d'Austria duchessa di Savoia (1567-1597), Atti del convegno internazionale di studi, Torino, 30 settembre - 2 ottobre 2009, Roma: Carocci

SÁNCHEZ, Magdalena, 2009, "Sword and Wimple: Isabel Clara Eugenia and Power", in CRUZ A. J., SUZUKI, M. (ed.), The Rule of Women in Early Modern Europe,. Urbana and Chicago: University of Illinois Press, 2009, pp. 64-79

SCHAUB, Jean-Frédéric, 2001, Le Portugal au temps du comte-duc d'Olivares (1621-1640). Le conflit de jurisdictions comme exercise de la politique. Madrid: Casa de Velasquez

SERRÃO, Joaquim Veríssimo, 1979, História de Portugal, vol. IV, Governo dos Reis Espanhóis (1580-1640), Lisboa: Editorial Verbo

SPAGNOLETTI, Angelantonio, 2003, Le dinastie italiane nella prima età moderna. Roma-Bari: Laterza

TAMALIO, Raffaele, on line, http://www.treccani.it/enciclopedia/margherita-di-savoia-duchessa-di-mantova-e-di-monferrato_(Dizionario-Biografico)/

VALLADARES, Roberto, 1998, La rebelión de Portugal: guerra, conflicto y poderes en la monarquía bispánica, 1640-1680, Junta de Castilla y León: Consejería de Educación y Cultura

VARALlO, Franca (ed.), In assenza del re. Le reggenti nei secoli XVI-XVII (Piemonte ed Europa), Firenze: Olschki

VARALLO, Franca, 1999, "La festa per il matrimonio delle Infante (1608)", in M. Masoero, S. Mamino, C. Rosso (ed.), Politica e cultura nell'età di Carlo Emanuele I. Torino, Parigi, Madrid, Firenze: Olschki, pp. 475-490

VARALLO, Franca, in corso di stampa, "Catalina Micaela en la corte de Saboya", in COLOMER, J. L. (ed.), Vestir a la española. Prestigio y Vigencia del Atuendo Español en las cortes europeas, Madrid: CEEH 